\title{
Shadowy Presences: Mobility, Labor and Absence in the Work of Dominican Photographer Fausto Ortiz
}

\section{Carlos Garrido Castellano}

To cite this article: Carlos Garrido Castellano (2017): Shadowy Presences: Mobility, Labor and Absence in the Work of Dominican Photographer Fausto Ortiz, Photography and Culture

To link to this article: http://dx.doi.org/10.1080/17514517.2017.1295708

Published online: 10 Mar 2017.

Submit your article to this journal $\asymp$

Q View related articles $\longleftarrow$

View Crossmark data 


\section{Photography \& Culture}

Volume XX-Issue X

March 2017

pp. 1-16

DOI:

$10.1080 / 17514517.2017 .1295708$

Reprints available directly from the publishers

Photocopying permitted by license only

(C) 2017 Informa UK Limited, trading as Taylor \& Francis Group

\section{Shadowy Presences:}

Mobility, Labor

and Absence in the

Work of Dominican

Photographer Fausto

Ortiz

\section{Carlos Garrido Castellano}

\begin{abstract}
This article aims to examine the ways in which contemporary art from the Caribbean, and specifically from the Dominican Republic, is analyzing mobility and human trafficking within a transnational context. In this case I will critique the work of the photographer Fausto Ortiz (Santiago de los Caballeros, 1970), who has reflected recently on the consequences of migration and displacement for Dominican cultural politics. Rather than addressing the representation of marginalized sectors and marginal forms of economy in the particular case of the Dominican Republic, I argue that Ortiz's photographic practice deepens and broadens the debates about race, citizenship and social inequality, forcing his audience to consider those issues as a central part of the everyday. While addressing those issues, this article tries to insert Ortiz's photographic practice within international debates on mobility, border practices and displacement.
\end{abstract}

Keywords: Caribbean, islands, migration, photography, transnationalism

Migration and mobility have been a central concern in recent Caribbean visual practices. The representation of slavery and of the Middle Passage are commonly confronted and linked to contemporary processes of voluntary and forced displacement. This focus has been key in placing Caribbean visuality within a transnational context, transcending the identification between regional imaginaries and tropical, insular landscapes. A big effort has been made to challenge the visual commoditization of Caribbean reality. A similar interest has pursued to insert Caribbean visual practices within a global arena (see Wainwright 20 I I; Kempadoo 2013 ; Stephens 20 I3; Mohammed 20 I ). In critical theory, authors such as Juan Flores (2010), Jorge Duany (201 I), Silvio Torres Saillant (1999) or Yolanda Martínez San Miguel (2003) have attempted to dismantle the nation-diaspora divide, pointing out the centrality of the "cultures of migration" (Martínez San Miguel 2003) for any understanding of the 
Caribbean cultural imagery. For those authors, mobility appears as a crucial element not only for those individuals or groups that are subjected to displacement, but also for the configuration of social imaginaries across the region.

Engaging with those debates, this paper aims to explore how mobility and labor are portrayed in Caribbean visual practices. In order to do that, I examine two series of the Dominican photographer Fausto Ortiz (Santiago de los Caballeros, 1970). Ortiz has developed a consistent artistic career since the 1990s, gaining international recognition at the end of the 2000s, when his work was showcased in major art exhibitions within and outside the region, such as Infinite Island (New York, Brooklyn Museum, 2007). Around that date, when his work became internationally known, Ortiz consolidated a preoccupation for addressing the contradictions of mobility and migration within the context of the Dominican Republic. This concern is best expressed in Ciudad de sombras (City of Shadows) and Remainders, two photographic series produced in the late 2000s. Both are specially bounded to marginal and conflictive modes of displacement. They depict situations of precariousness and instability, forcing the spectator to challenge her expectations towards Caribbean bodies and landscapes, and dismantling the economic and racial discourses behind Dominican nationalism.'

In this article, I attempt to place Ortiz's photographic practice within the context of Caribbean cultures of migration. By looking at Ciudad de sombras and Remainders, I argue that, although dealing with specific local predicaments, the concerns with labor, migration and trafficking bodies present in both series cannot be isolated as a national phenomenon. My interest here is to show that Ortiz's exploration of the Dominican landscape of (im)mobility opens new ways of understanding the predicament of Caribbean displacements as a global phenomenon. Issues of difference and proximity/distancing have regulated in many cases the cultural debates around the links between Haiti and the Dominican Republic. The approximations to that predicament developed by
Dominican artists share those issues (see Casa de América 2002; De los Santos 2003; Ginebra 2009; Miller 2012). Without dismissing such approaches, in this case I would like to suggest that a major part of Ortiz's work alludes to a liminal space related to the cultural and political relations in La Española, a space delimiting notions of political economy and habitability in the Caribbean at large. In that context, the question on coexistence is strongly linked to the visibility or invisibility of communities, as well as to governability, forcing the spectator to question human displacement in relation to the widespread of Caribbean visual practices within a transnational context. "We remain labelled but nameless images," suggest Christopher Cozier and Flores (2012), 9) in dealing with Caribbean contemporary artistic practices. In this article I attempt to show how this concern is present in Ortiz's photographic imagery.

Herein I examine how Ortiz challenges the image of the Caribbean as a paradisiac, exotic location by depicting bodies and histories that are often excluded from the Dominican national imaginary. The shadows and inanimate bodies that center the image composing both series constitute, I will suggest, a troubling presence haunting Caribbean landscapes of migrant labor and mobility. Rather than describing or narrating peripheral presences, Ortiz's photographic practice is proposing an alternative view of Dominican citizenship, one implying an active response and not just a documentary gesture. The main argument of this paper, therefore, is that Ortiz's work transcends the direct representation of marginal fluxes, drawing a link between the marginalization of subjects and bodies, the configuration of the Dominican nation, and the impact of neoliberal capitalism across the Caribbean region.

\section{The series}

Ciudad de sombras (2007) depicts the urban landscape of Santiago de los Caballeros through the lack of visibility of part of its inhabitants. ${ }^{2}$ A group of shadows in movement are outlined over the walls, indicating a reality that cannot be perceived 

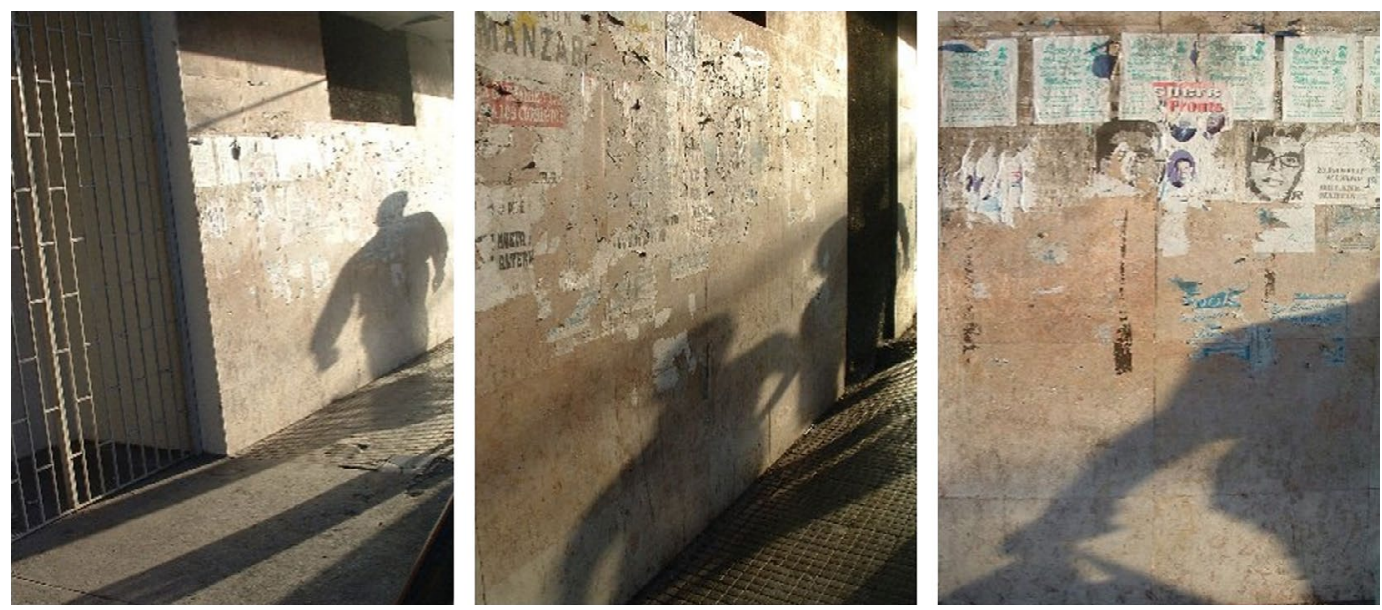

Figure I. Fausto Ortiz, "Aproximaciones," Ciudad de Sombras series, 2007. Digital photography. Courtesy of the artist.
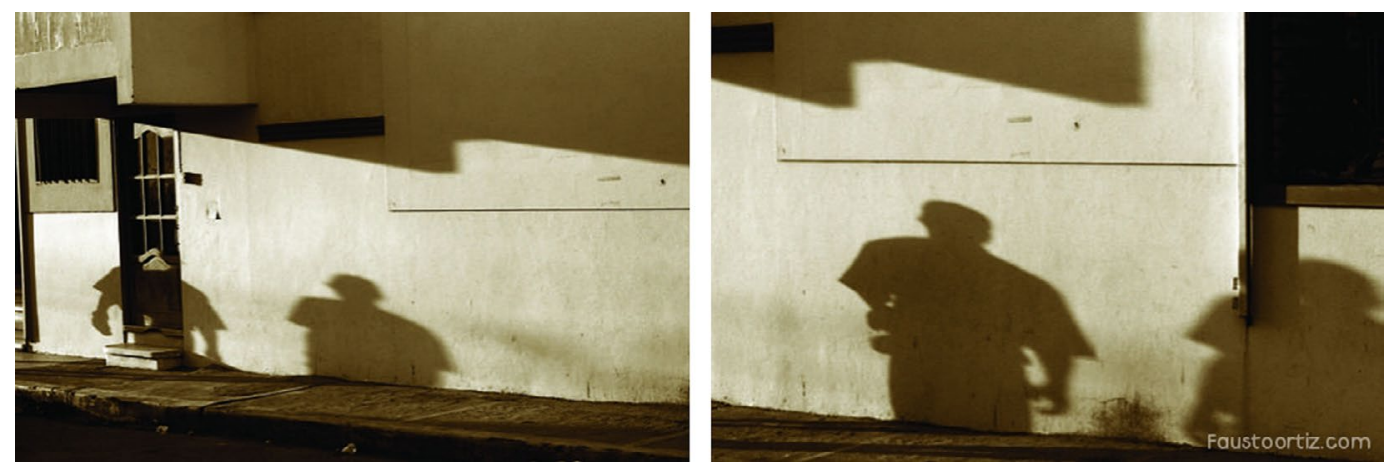

Figure 2. Fausto Ortiz, "Ciudad de Sombras," Ciudad de Sombras series. 2007. Digital photography. Courtesy of the artist.

by the spectator (see figures I-5). Becoming shadows, errant figures whose position and identity can be only guessed from their reflection, those figures render a vision of a community marked by its estrangement, by its inexpressiveness. Those silhouettes constitute, however, an inseparable layer within the historical materiality of the walls, one that imprints its presence to the urban texture and embodies the contradictions of misrepresentation. Ciudad de sombras portrays the imagery of downtown Santiago de los Caballeros, the second major city in the Dominican Republic. By looking at those the images, however, we could not know in what part of the city the pictures have been taken, nor the identity of the photographed persons. The only recognizable elements of the scenes come from the remnants of some messages fixed to the wall addressing political issues and key figures of Dominican political process, but these also seem to fade. The image titles are equally ambiguous, and are used to suggest particular interpretations - Laberinto (Labyrinth), Sombras Pasajeras (Temporary Shadows), Aproximaciones (Approximations) - or the relation among the characters - Procesión (Procession), Partners.

Although they modify the urban space where they are inserted, the shadows rarely occupy the whole wall, being relegated to the inner part 

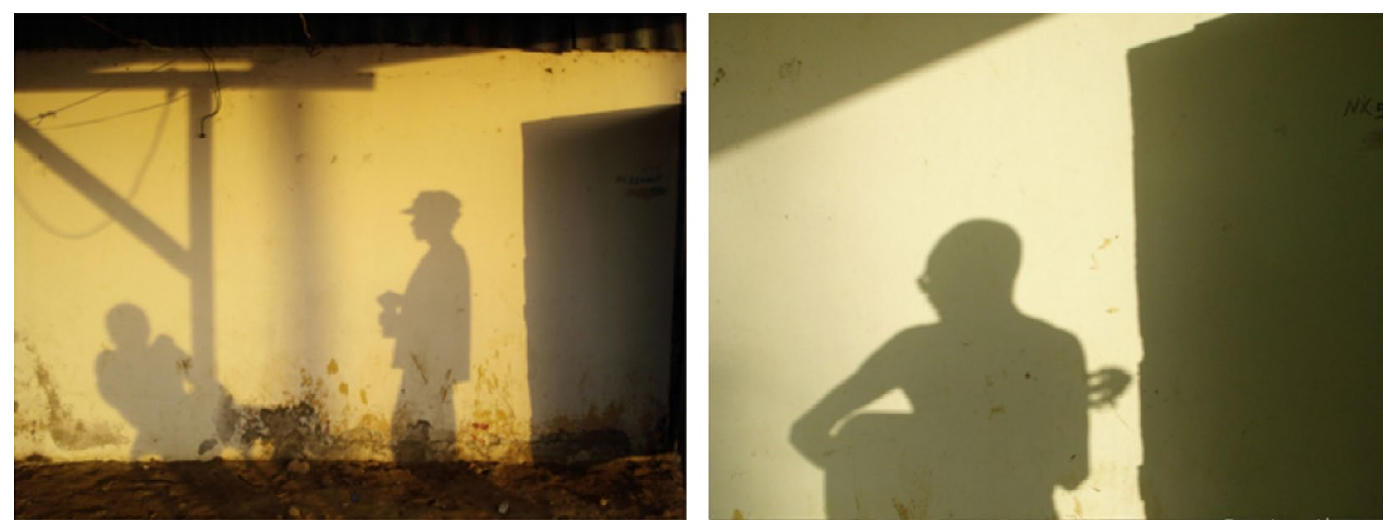

Figure 3. Fausto Ortiz, "Peace Piece," Ciudad de Sombras series. 2007. Digital photography. Courtesy of the artist.

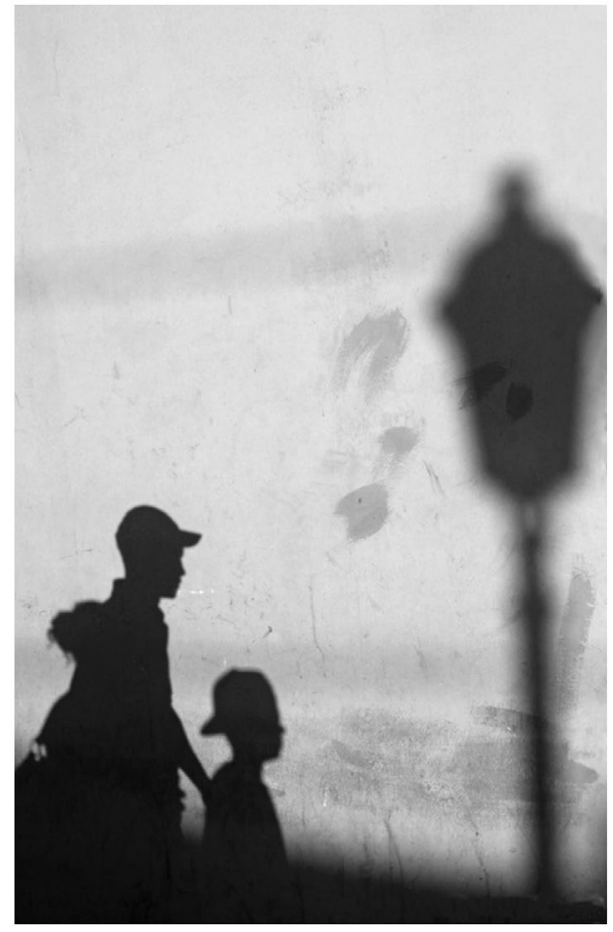

Figure 4. Fausto Ortiz, "Laberinto 2," Ciudad de Sombras series. 2007. Digital photography. Courtesy of the artist.

of the image. This displacement is reinforced by the subjects' movement, captured while walking. Whereas the human figure holds the prominence of the scene, some photographs also include specific references to street furniture such as lampposts, traffic signs or parking meters. In those cases, the object's shadow appears bigger than the human form, creating a vertical counterpart to the inclining, diagonal shape of the walkers' silhouettes. This does not eliminate the sense of nakedness, of simplicity of the photographed spaces. In rare cases, moreover, a sense of narration is pursued. Ortiz shows mostly isolated figures. In the group portraits, the subjects are often walking in divergent directions or clearly separated one from others. Some exceptions can be found in photographs like Fragmentos de paz (Peace Fragments), where people are presented in more relaxing, engaging attitudes, such as playing music, or in Laberinto, where we can identify a family walking together, the father guiding the steps of the children.

The other series of Ortiz dealing with precarious processes of mobility took the name of Remainders. Located in a tropical coastal landscape, the images show parts of mannequin bodies deposited by the sea as evidence of a shipwreck. While in some cases we witness the inexpressive faces oscillating with the tide, in other occasions the dispersed members lie under the sand, buried. In all the pictures, however, a feeling of abandon and decay appears, suggesting the idea of dispensable lives. The sense of tragedy is reinforced by the calm nature of the landscape, unaltered by the accident, and also by the perfectness of the 

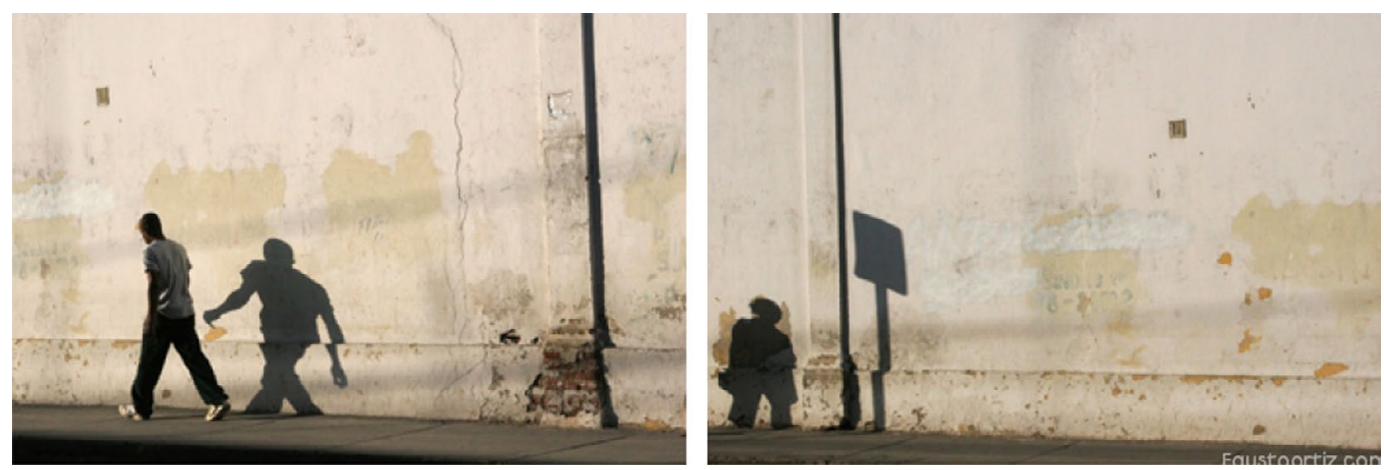

Figure 5. Fausto Ortiz, "Sombras pasajeras 2," Ciudad de Sombras series. 2007. Digital photography. Courtesy of the artist.

bodies and fragments, which appear without a mark. We cannot find a clear connection between the different characters populating the scene: while some are about to disappear, others seem to enjoy the day. Although we are in a shore, water is outlined in several cases, creating a horizon reinforced by the horizontal alignment of the bodies. The use of limbs and torsos complements the idea underlined by the title of showing remainders of a wider totality recently disappeared. It also emphasizes the contrast between the perfection of the bodies and their outcast character, presenting the scene as a consequence of traumatic experiences. Mannequins, in that sense, appear as an integral part of the economies of movement and consumerism that lead to, according to Sheller, "forms of symbolic violence and cultural appropriation" (Sheller 2003, 4). Inserted in a tragic insular tropical landscape, they become part of what Ann Laura Stoler (2013) has called "imperial debris," countering both the idyllic image associated to the Caribbean and the role of touristic sheltered isolation attached to tropical insularism. What the shipwreck is telling us, in other words, is that any process of mobility is indissolubly linked to global circulation of money and products. That circulation, as Sheller points out $(2004,15)$, not only tolerates but also increases transnational processes of inequality.

As in Ciudad de sombras, several interpretations are possible here: a direct reading of the feminine condition of the mannequins could pose issues of sexual labor and forced migration. The surroundings of the shipwreck point to the illegal migration of Dominicans to Puerto Rico in yolas (small handcrafted vessels used for this kind of transit) through the Mona Canal. The open character of the series can be seen, then, as a dispositive used by the artist in order to make Dominican border reality problematic without specifying or privileging any particular interpretation. As none of those visions prevail over the rest, the viewers are forced to guess the possible meaning of the images (see Figure 6). When asked for the meaning of Remainders, Ortiz answers cryptically: "The debris of the sea is what the sea expels; in this case, I wanted to suggest the idea of waste, mutilation, expulsion."'3 Similarly, Ciudad de sombras is also located within a broader geography in Ortiz's interpretation:

\footnotetext{
I believe that the best way of representing the person who enters and leaves briefly the city without leaving any trace is through the shadow. The shadow is projected onto the city, in the walls, and those walls are built by many of those persons, they are not used solely to shelter them ... I mean, I am talking in this case also about the Dominicans living in New York, in Spain, to say something. Many people understood my use of shadows as linking the images to skin color, but it does not necessarily have to do with this. ${ }^{4}$
} 


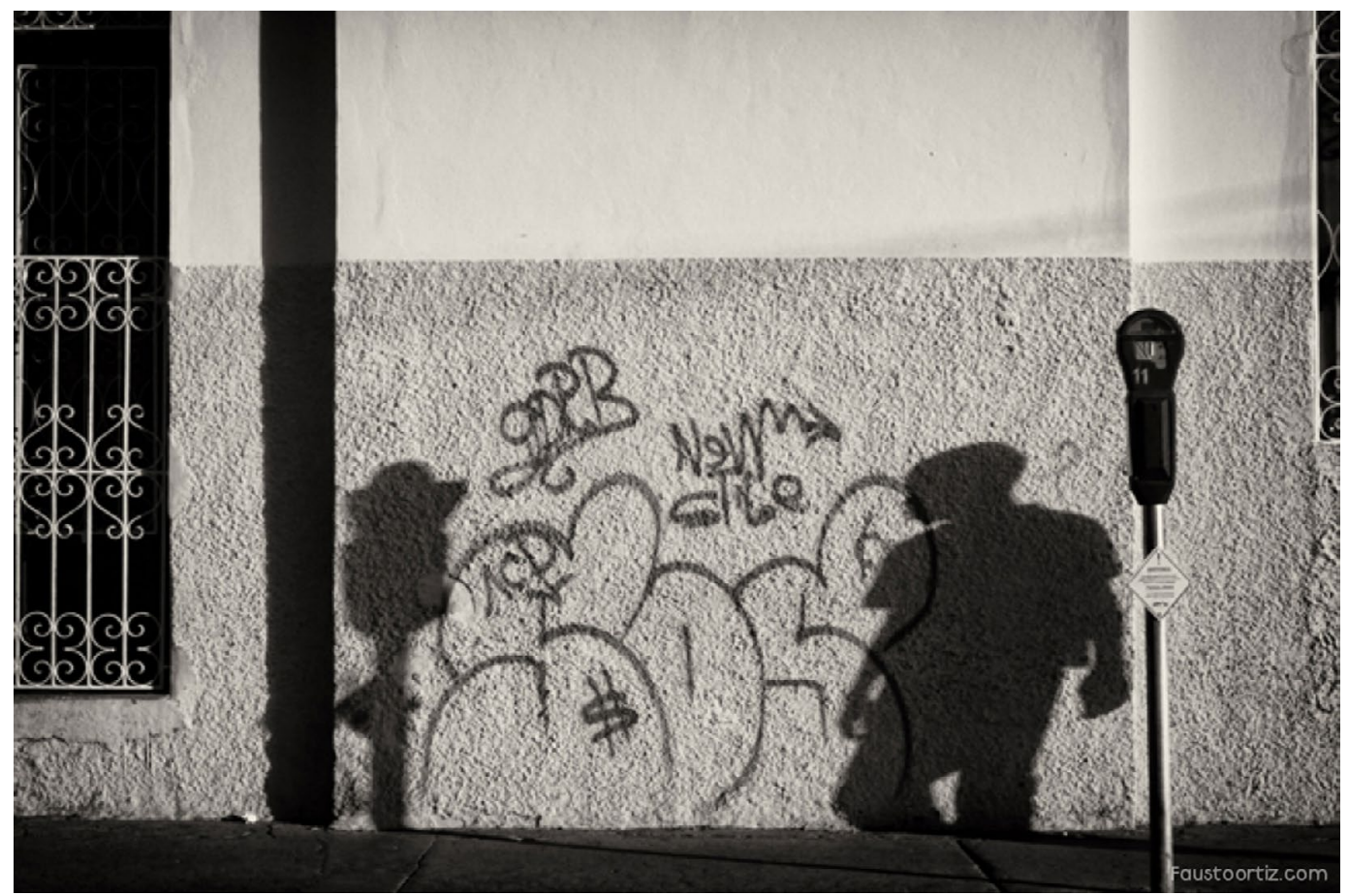

Figure 6. Fausto Ortiz, "Number Eleven," Ciudad de Sombras series. 2007. Digital photography. Courtesy of the artist.

As we will see, the opacity and ambivalent tone of both series does not imply lack of attention to the context; on the contrary, it defines a way of linking and spacing marginalized and misrepresented histories, pointing out the complexity that characterizes contemporary experiences of mobility.

\section{East and West: reframing the Dominican gaze}

Ortiz's photographs are concerned with the overlapping of heterogeneous histories and conflicts, which are braided through several elements, among them mobility, (in)visibility or race and racism. In this section I will focus on the last two terms, attempting to connect them to the Dominican Republic geopolitical imagination. Both series, as we will see, portray the central roles that migration and mobility play in the configuration of Dominican nationalism (see, for example, Martínez
San Martínez San Miguel 1998, 200 I; MartínezVergné 2005; Itzigsohn 200I). East and West are more than two cardinal points in the Dominican spatial imaginary. The West is undoubtedly represented by Haiti, an ever-present and unmentionable reality in the country. Sara Hermann has recently alluded to how this abrupt extirpation and uncanniness of one of the cardinal points is "one of the most violent acts that can exist." (Hermann 2012, 86). Haiti and the Dominican Republic are not just separated by a border, but also by a long history of conflicts and political difference: the Dominican Republic gained independence from Haiti, which controlled the totality of the island from 1822 until $1844^{5}$. The independence of the country was linked to the events that followed the Haitian Revolution, when the island became divided in two, one part controlled by the French until 1809 and another by the nation that had just gained independence. Given the passivity of both 


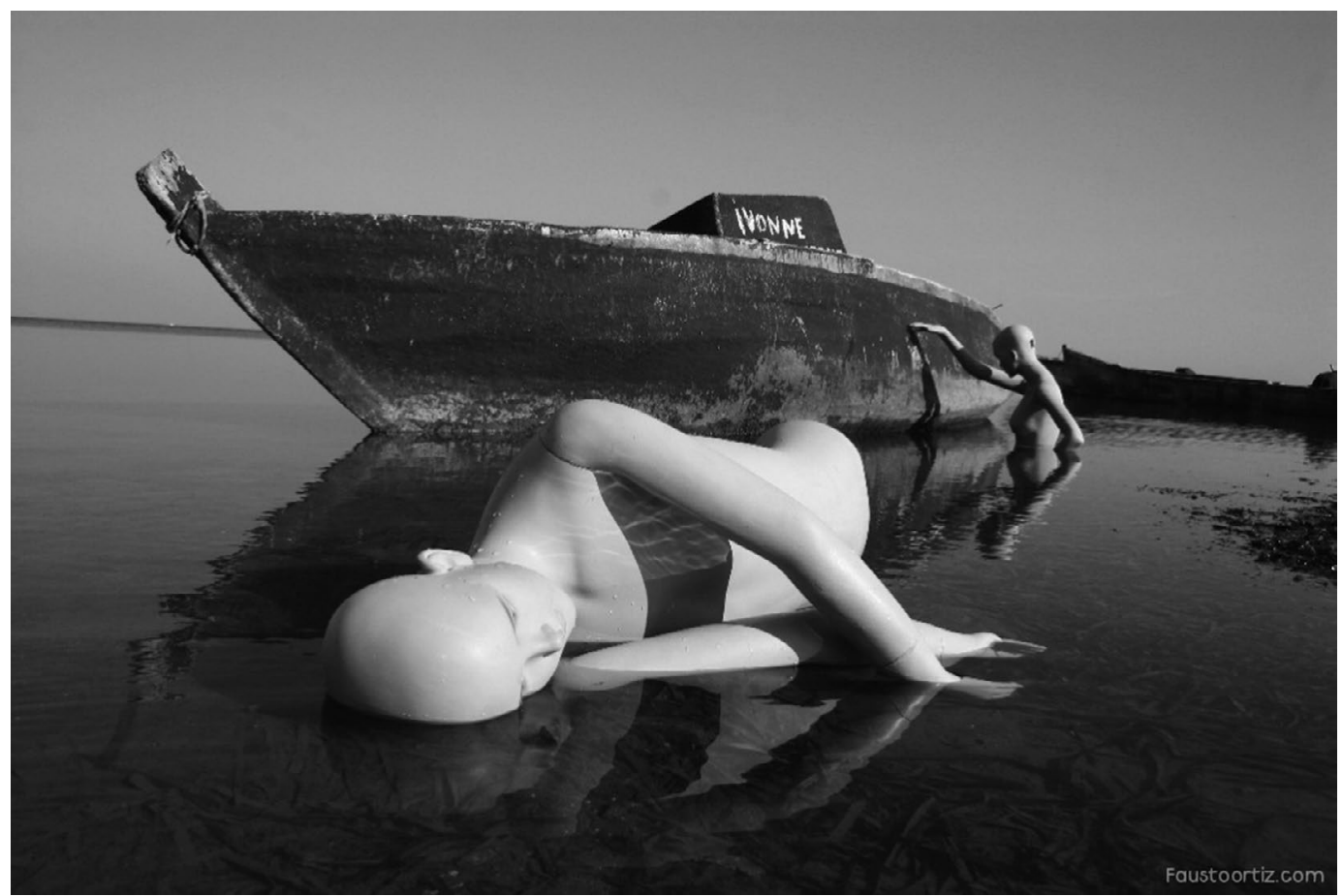

Figure 7. Fausto Ortiz, "Náufragos," Remainders Series. Digital photography. Courtesy of the artist.

Spain and the international powers toward the independence of the Spanish side of the island, the Haitian government of Boyer occupied in 1822 the other part, reintroducing the abolition of slavery and imposing the French civil code. One century after, the dictatorship of Rafael Leónidas Trujillo instituted anti-Haitian policy which lead to the expulsion of many Haitian citizens and to several massacres ${ }^{6}$. The legacy of this historical conundrum has remained a central issue in the relations between both countries until the present moment, when the situation is aggravated by the massive deportations of Haitian and Haitian-origin citizens? Contemporary Dominican art has dealt extensively with Haiti and "the Haitian issue," both in clever, subtle and more straightforward ways. Performance artist Sayuri Guzmán, for example, has braided the hair of Dominican and Haitian women together, bounding them ${ }^{8}$. More radically, Caryana Castillo wove a flag mixing both countries', wearing it while walking around the historic Ciudad Colonial of
Santo Domingo. Finally, David Pérez's "Karmadavis" work for the Latin American Pavilion of the 2013 Venice Biennale took the form of a collaborative performance between a Haitian and a Dominican disabled citizen (see Fumagalli 2013, 20I5). Those are just some recent examples of a topic exploited time and time again in Dominican visual practices?.

The East also holds an almost mythical appeal in the Dominican geographical imagination. In this case, it is commonly associated with illegal migration to Puerto Rico through the Mona Canal. This journey means the entrance in US territory, but also constitutes a dangerous passage that has cost many lives. The drama of the yolas is usually related to questions of privilege, acceptance and success: the migrant who reaches Puerto Rico enters the "promised land," although migration is, in many cases, also associated with precariousness and unwanted jobs. Furthermore, for many Dominicans the process of dealing with the American racial divide also implies a redefinition 


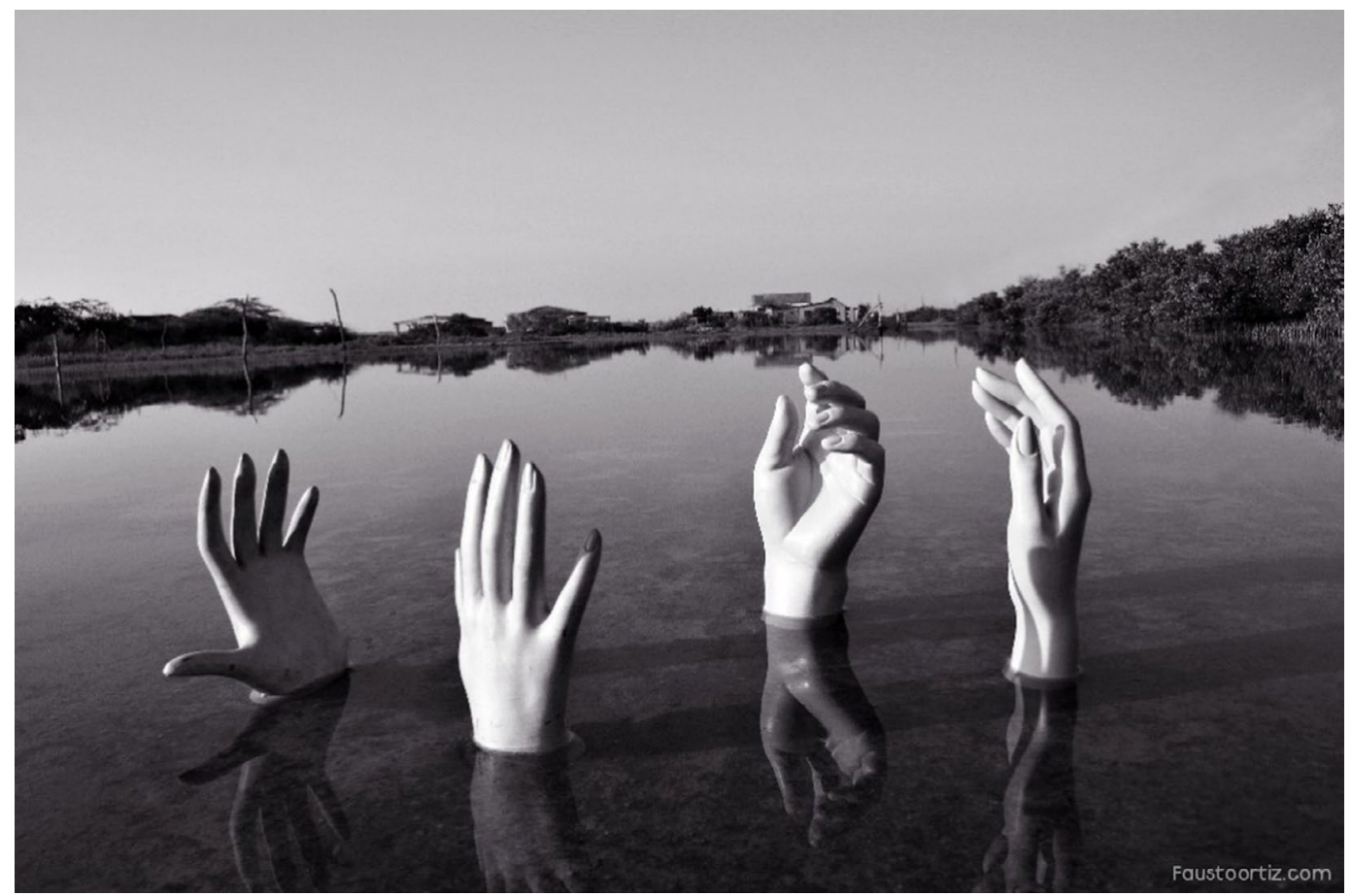

Figure 8. Fausto Ortiz, "Horizontes de paz," Remainders Series. Digital photography. Courtesy of the artist.

of their bodies and racial identities. As it happens with the West, the East has also been a familiar focus for Dominican artists. For instance, in 2003 the Shampoo Collective created D'La Mona Plaza, a project that shocked artistic audiences in its time and that reached a huge public not familiar with contemporary art. The project advertised in the Dominican media the construction of a big shopping mall in the Mona Canal, which would provide help to shipwreck survivors and migrants in yolas. The most interesting part came when the media did not acknowledge the prank and started discussing the viability of such shopping mall.

East and West are behind the gaze constructed in Ciudad de sombras and Remainders. However, I believe that it is difficult to identify each series with a cardinal point. On the contrary, an alternative view of the Dominican imaginary, one in which both cardinal points are confused and confronted together, emerges in both series.
Ortiz's photographs show that the construction of Dominican identity and its national and racial Other(s) cannot be confronted separately. The series force the (Dominican) spectator to rethink her/his position as necessarily touched by heterogeneous and interconnected experiences of marginalization. Precisely this ambivalence troubles the connection between the photographed space, the addressed predicament and the artistic interpretation, for the lack of presence of their protagonists (shadows in the first case, lifeless mannequins in the second) seems to reinforce the unfruitfulness of any identification with "real" referents. Authenticity is excluded in Ortiz's portraits, and that reinforces the concern for identification that shadows express.

In the case of Ciudad de sombras, the first reference that comes to mind is that of the landscape of labor in La Española Island and the increasing processes of miscegenation represented 


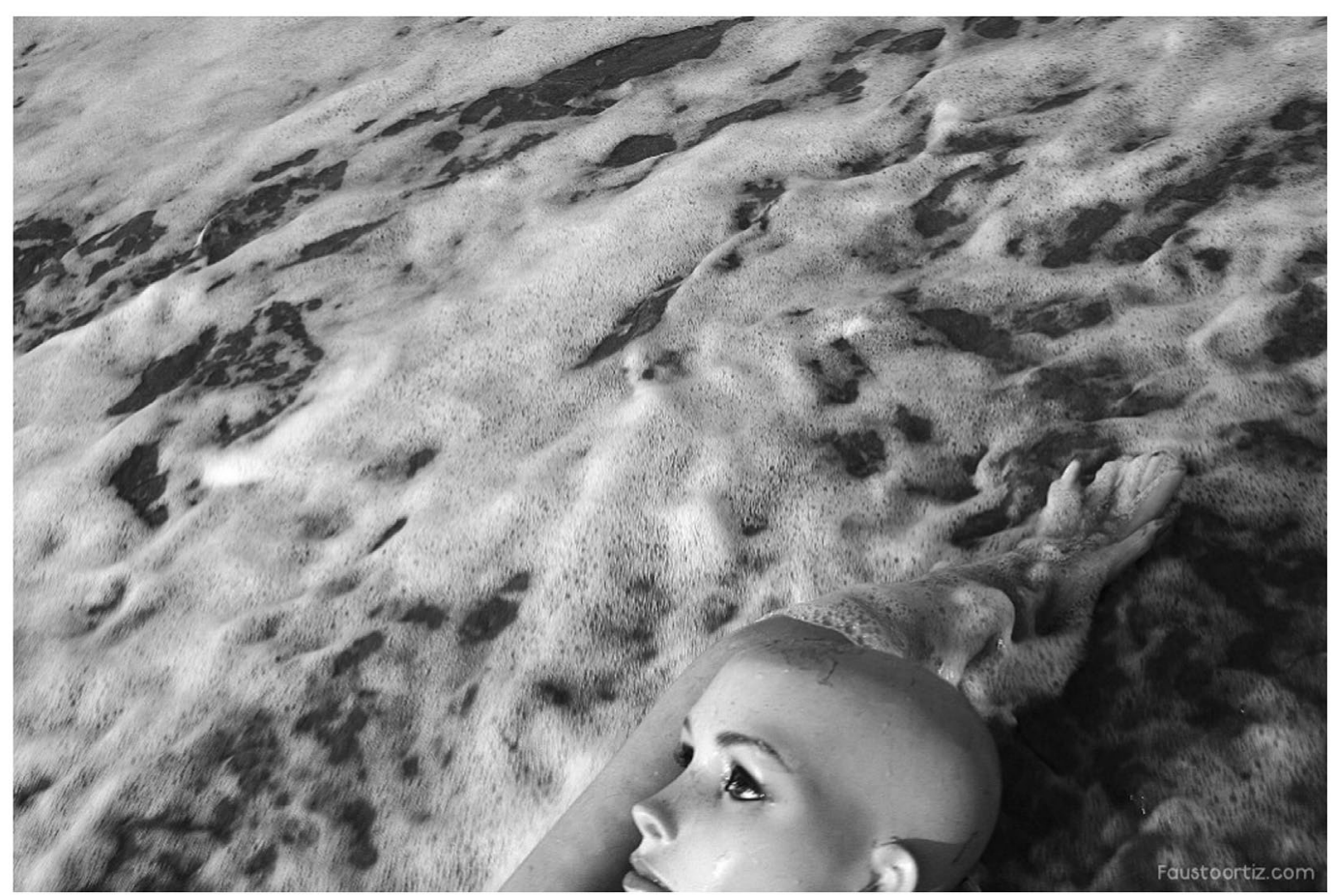

Figure 9. Fausto Ortiz, “La ida," Remainders Series. Digital photography. Courtesy of the artist.

by generations of Haitian-Dominican citizens. The sombras (shadows) are black presences that come and go without imprinting their presence in the city walls. However, they also allude to an impossibility of identification, echoing the mobility across both countries, but also the mixed condition of most Dominican citizens (contrary to the assumed blackness of Haitians, the Dominican population tends to define itself as "mulatto"). Rather than depicting an equally unfruitful pessimistic or optimistic vision of mobility in the specific context of Santiago de Los Caballeros, Ciudad de sombras outlines the centrality of transnational cultural processes, "familiarizing" them (Hannerz 1996).

A general concern with exclusion, absence and misrepresentation is also present. Apart from the obvious platonic resonance to the Cavern Myth, the black of the shadow recalls the claim of the Haitian Revolution about the blackness of all the citizenry, portraying therefore a utopian message of togetherness and commonality (a sense perhaps more difficult nowadays than in 2007). Produced before the crisis of citizenship that lead to the deportation of Haitian citizens in 2013 , the series already announced many of the ingredients that brought La Española to an international focus in the last years. The "Haitian problem" was a silent but persistent one until recently; a situation mixing incomprehension, racism and economic instability in equal parts. That is likely why there is no protagonist in Ciudad de sombras. Ortiz's photographs are not images of Haitian citizens, nor they depict eye-catching conflictbased situations. Instead, what the artist offers is a negative of a quotidian situation of sharing a common space collectively $y^{10}$. Ortiz has attempted to keep control of the interpretations made of the series, challenging especially those that identify the series in simplistic ways with the subaltern situation of Haitian migrants. The series also already 


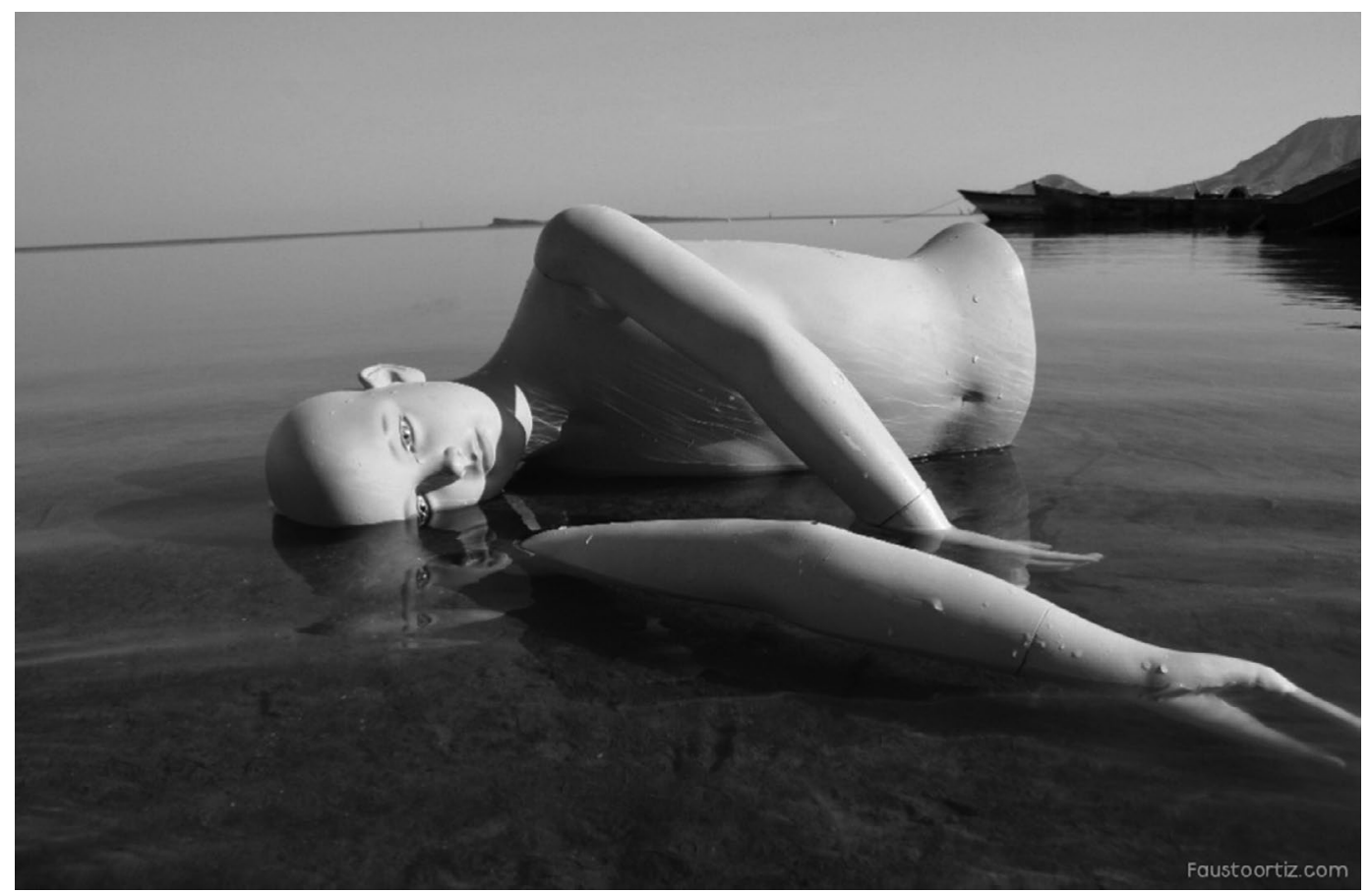

Figure I 0. Fausto Ortiz, "Sueños líquidos," Remainders Series. Digital photography. Courtesy of the artist.

perpetuates this by refusing direct thematization and sensationalism.

The shadow also allows Ortiz to pose questions concerning the visual presence and representation of migrating communities at large. Dealing with the 'unhomely' (Enwezor 2006), Ciudad de sombras examines the precarious lives of the migrant force in transitional spaces, highlighting the way in which they are socially transformed and culturally reshaped. Many of its protagonists are captured in everyday situations. In this sense, it is worth comparing the menacing atmosphere of Aproximaciones or Ciudad de sombras with scenes such as Peace Piece, for example. In this case, the persecutory tone of the two first photographs gives way to a calmed situation: one of the photographs of the diptych portrays a conversation among two subjects, and the other a man playing guitar. Movement and displacement are not present in this case, suggesting the permanence or the repetition of those actions across time. In Laberinto (Labyrinth), the oppressive feeling suggested by the title contrasts with the gestures of the three figures composing the photo. Those two photographs are deprived of any urgency. They could belong to any context, to any chronology. Those two examples also propose a different kind of relation with the urban milieu: the characters of those pictures do not seem to be escaping from anything, and that easiness seems to suggest a deeper and more lasting imprint in the city walls.

Remainders could also be suggest a straightforward interpretation: an exploration of the migration of Dominican citizens through the Mona Canal (see figures 6-10). However, a more profound look at the images reveal a similar interest in evading a direct confrontation. Remainders translates the focus to a dystopian notion of Caribbean nature. The only element that transfers some comfort to the spectator is the surreal character of the scene. In that sense, 
Ortiz approaches the problems derived from the complexity of coexistence in the "quiet tragedy" of marginal migrations. A sense of isolation emerges, distancing the viewer from any kind of imperative of the sublime. If we can associate shipwrecks with both the sublime enjoyment of a contemplator, and the forceful energy of the sea (see Guillén 2004, 19-25), we cannot find any of those elements here. The figure of the Romantic contemplator of nature seems to have been exiled, for the apocalyptic tone of the picture excludes any possibility of witnessing it. In front of those shipwrecks we are alone. Whereas in Ciudad de sombras the difficulties in defining an encompassing citizenry were presented through the generic character of shadows, in this case strangeness and temporal and corporal dislocation work in the same way, expelling us from the pathos of tragedy. This sense is reinforced by the relation between the mannequins and the landscape. Unlike the characters of Ciudad de sombras, integration does not seem possible in this case: on the contrary, the bodies appear as debris, either consumed or expelled by the sea.

\section{Shadowy presences: ambivalence and accumulation}

An interesting element distancing Ortiz's photographs from the artistic imaginary dealing with the Dominican geopolitical landscape is precisely driven by the ambivalence of both series. The artist is careful enough to gauge a literal approach to the issues dealt with or an illustration of social or political predicaments. Consider, for example, "Aproximaciones," one of the most symbolic photographs of Ciudad de sombras. In this triptych, both the shadows and the walls are defined by an increasing tension between presence and disappearance. The image at the left suggests an abstract menace, portraying a human silhouette with clenched fists walking towards a close fence. This tension materializes in the photograph at the right, where the rotundity of the figures gives way to an elusive figure carrying what seems to be disposal. This interpretation is reinforced by the layers of posters and photographs that we find in the wall: abstract in the left photograph, they become clearer at the right, where we find a disappearing portrait of Joaquín Balaguer surrounded by illegible lists and group of portraits. This composition immediately recalls the disappearance of political enemies that took place under the government of Balaguer in the period known as "Los doce años" (The twelve years)". Between 1966 and 1978, Balaguer attempted to consolidate the transition from dictatorship to democracy by developing a policy of economic development and urban modernization, and also by appealing to the most popular sectors of Dominican society. The disappearances and political murders, however, continued after the Trujillo dictatorship, constituting the dark side of the economic growth that defined the official image offered by the government in that period. The juxtaposition of layers and shadowy presences in "Aproximaciones" reveal the continuities between the political violence behind the disappearances and the contemporary exclusion of migrants. The result of both processes is here portrayed as a continuum by the figure at the right carrying disposal. This figure condenses the contradictions between the country's official image and the informal mechanisms undertaken to achieve or maintain it both during the government of Balaguer and in the present moment. The bodies personified by the silhouettes hold an ambivalent relation with the "solid" reality of the wall: they are portrayed as menacing presences, but also as carriers of disposal. They appear as accomplices and victims of a violence that is never openly defined, just suggested. In that sense, the presence of the president gives the title of the triptych ("Approximations") a definite shape, endowing the scenes with a threatening atmosphere. Furthermore, it reveals the difficulties in confronting situations of violence and marginalization: as the desaparecidos constitute in many cases a non-traceable presence, the position of the migrants within Dominican cities appears subjected to equally oblique and non-evident menaces.

Looked at from the perspective offered by "Aproximaciones," Ciudad de sombras appears 
elusive and ambiguous, but also deeply rooted in the continuity of violence and repression within the Dominican context. A straightforward reading of the series renders it a tribute to the role played by Haitian migrant workers in the construction of Dominican cities landscape. Not by accident, the photographs were taken in Santiago de los Caballeros, the birthplace of Ortiz, and they depict Haitian individuals and families living there. When asked who the people are depicted through the shadows, however, Ortiz points to the centrality of anonymity in every city, therefore restricting the identification of the shadows with Haitian bodies:

But certainly those silhouettes meant a lot for me in that particular moment, but now they came to represent anonymity. The anonymity of the city. Because of that I mentioned now about the formal and the informal city; in all contemporary cities you have groups that do not count; groups that are there, but that do not appear anywhere. The "absents."'Those who does not have a number, an ID, a code, or simply those who stay in the shadows of the city, being required and used only when labor force is needed. That happens everywhere. Many countries have the same situation. $^{12}$

As we have seen in "Aproximaciones," this is only partially true, since the triptych locates the photographs beyond the predicament of migrant labor through the ambiguity and interchangeable character of the shadow.

Something similar occurs in Remainders. Three possible readings thus overlap in this series: first, the fact that all the bodies are female recalls sexual economy and displacement ${ }^{13}$, one of the most traumatic forms of transnationalism (see, for example, Brennan 2004; Fusco 1996; or Kempadoo 2004). At the same time, the composition of some of the images, with the sunken figures in front of a paradisiac landscape, reinforces the tragic tone of the photographs, alluding to the shipwrecks of Dominican illegal migrants to Puerto Rico. Furthermore, all the bodies are white and shaped and have light-colored eyes, an element that contradicts the interpretation of the scenes as shipwrecks of Dominican migrants. As in Ciudad de sombras, the three possibilities are connected through the accumulation of referents. In this case, the photographs locate mobility at the core of a political economy of corporal and sexual representation that replicates and challenges the official values concerning gender and race; primarily Western whiteness and decency appear not only as a symbol of social and economic status, but also as an indicator of national belonging.

The photographs composing both series are, thus, distanced from a direct thematization of migration. They allude to the political economy of the complex network of mobility practices that lie behind the official image of rigid borders in the context of La Española, without forgetting the historical causes and particular conflicts shaping Dominican history. Ortiz escapes from an identification of the migrating subject as other, and questions its visibility within the public space. The human bodies present in both series link several temporalities and situations, pointing out at the pervasiveness of different processes of marginalization and violence.

\section{Conclusions}

In this essay I have attempted to show that transnational relations are rethought in Ortiz's work from a complex perspective. Instead of simply asserting a vision of them based on difference and marginalization, Ortiz employs opacity to unearth the contradictions implicit in the Dominican context, transferring the precariousness associated with labor migration and prostitution to the very core of present-day debates on citizenship and national identification. In so doing, he troubles the social, transnational landscape where those exchanges are located. At stake here is how to approach situations of inequality associated with transnational processes of personal and economic movement without falling into a narrative of anecdotal readings. In this text I have shown how Ortiz does so by juxtaposing historical referents and 
everyday actions or by erasing the identity of the photographed bodies.

Through the analysis of some of the photographs composing Ciudad de sombras and Remainders, I have outlined how the bodies appearing in the pictures should be located within a transnational framework, opened to multiple interpretations more than depicting and individuating any community. Ortiz generates a landscape where part of its inhabitants cannot recognize themselves, being consequently excluded from representation. What those bodies suggest is a generalization of precariousness associated with urban experiences of empowerment and marginalization. Their negative presence, however, suggest that any conception of that landscape is unviable without considering its absences. In that sense, Ortiz challenges the human vacuums existing within transnational economic exchanges, exploring the ways in which those exchanges exclude the active voices of many of their participants. As shadows contaminate our view of the inert space of the city, they corroborate their participation in the making of spatial uses of the everyday. Ortiz's silhouettes express, thus, a minor resistance (De Certeau 1980, 30-31), and a concern on the need to revise the inclusiveness associated with public spaces.

In Ortiz's series, vulnerability is portrayed as constituent of citizenship. Although a first glance would suggest an identification of both series' figures with marginal subjects, the ambivalence and overlapping of histories the photographs portray points to the centrality of mobility and precariousness in the constitution of Dominican citizenship. In both series, examining human trafficking becomes important from the moment that both transnational sex practices and labor migration are not thematized and isolated, but located as crossing all the spheres of the Dominican society ${ }^{14}$. In that sense, Ortiz propels us to consider that no image of transnational connections in the Dominican case is possible outside of those "marginal movements" (Puri 2004).
Furthermore, we have seen how both Ciudad de sombras and Remainders grapple with the political economy of race and gender within the Dominican context (Howard 200 I; Sargás 2002). By the contrast posed by black silhouettes and white mannequins, Ortiz dismantles the distance between self and others, and the racial implications implicit in the process of definition of Dominican nationalism. As the representation of borders are challenged and finally excluded through the opacity of shadows and the unreal appearance of the sunken bodies, Ortiz challenges straightforward interpretations of racial difference. By portraying voices and processes that lie behind the glance of the modernization of the country, Ortiz rethinks the corporeal logic of representation in the Dominican context, including Dominican subjects not as privileged viewers, but as part of the same predicament.

Ortiz's work conveys a double interest: while addressing particularly sharp issues for the configuration of Caribbean societies, such as accessibility, mobility and nation building, he also demonstrates an interest in generating a terrain where particular issues can be expanded and confronted outside thematization. Concerned with the ways in which Caribbean artistic discourses are consumed, tokenized and commoditized, he often separates the use of artworks from a mere illustration of theory and social concerns, producing photographs that capture the different maneuvers of representation taking place in the public domain. Ortiz's artistic practice is, in that sense, not addressing phenomena that occur at the margins, nor addressing "problematic" issues. Rather, he is questioning the debates on the economic and political relations that lie at the center of postcolonial Caribbean societies.

In Ciudad de sombras as well as in Remainders, we are confronted by decisive questions: Who are the shadows and denied bodies of any given urban reality? What kind of relations do they maintain within the contexts that they inhabit? In what way do they belong to those contexts? These questions can then be considered as effective approaches 
to interrogate contemporary (Caribbean) cultural practices. For migrations and displacement imply not only a vision of fluidity, but also one of immobility, precariousness and restriction. My reading of the work of Fausto Ortiz has attempted to show, therefore, that Caribbean imageries are proposing new ways of understanding conflict and change from a wider perspective, to one which escapes restrictive and monolithic visions. By addressing the cultural and economic exchanges along the Dominican borders, Ortiz situates himself and the viewer within, and against, a landscape wherein both can be disoriented.

\section{Acknowledgements}

This work was funded by a post-doctorate fellowship granted by the Portuguese Fundação para a Ciência e Tecnologia (FCT). The research developed here was produced over several long-term research stays in the Dominican Republic and the United States. The final version of the article benefitted from the comments of Nikizzi Serumaga. Special thanks to her and to Fausto Ortiz.

\section{Disclosure statement}

No potential conflict of interest was reported by the author.

\section{Notes}

1. The imaginary of Dominican national identity has traditionally been associated with four elements: the national territory, Spanish language, Catholic religion and racial miscegenation. All of those elements, as we will see, reveal themselves to be problematic and contradictory.

2. Santiago de los Caballeros is the second biggest city of Dominican Republic after Santo Domingo. Located in the landlocked agricultural and stock region of Cibao, the city is infamous for maintaining a more conservative atmosphere than the capital. However, Santiago is also a vibrant economic center, which causes significant social disparity among its population.

3. "Los desechos del mar es lo que el mar expulsa hacia afuera; en este caso yo pretendía dar esa idea de despojo, mutilación y expulsión." My translation. (Garrido Castellano 20I I).

4. "Yo creo que la mejor forma de representar a esa persona que entra y sale de manera fugaz a la ciudad y no deja huella es a través de la sombra. La sombra que se proyecta en la ciudad, en las paredes, y esas paredes que muchos de ellos construyen, definitivamente no sólo sirven para albergarles...Digo, hablo en este caso también de los dominicanos que viven en Nueva York, o en España, por decir algo. Mucha gente entendía que el hecho de que fueran sombras lo estaba vinculando al color de la piel, pero no necesariamente se trata de ello." My translation. (Garrido Castellano 20 I I).

5. The "liberation" of the country from the Haitian dominance in 1844 still plays a central role in the popular Dominican imaginary, conditioning both the racial views of self and Haitian others, and the present predicament between both countries.

6. Trujillo's anti-Haitian campaign reached its maximum with the Parsley Massacre of October 1937, when the Dominican military killed thousands of Haitians near the border.

7. The crisis affects not only Haitian citizens, but also individuals born in Dominican Republic, since the law regulating the expulsions retroactively denies Dominican citizenship to any person born on Dominican soil after 1929 of undocumented foreigners.

8. The action, called Trenzados, implied weaving together the hair of eight Haitian women and eight Dominican women. On Guzmán, see http://hemisphericinstitute.org/hemi/es/enc09-performances/item/56-09-sayuri-guzm\%C3\%A In

9. The work of other artists, such as Giuseppe Riggio, Jorge Pineda or Patricia Castillo could also be mentioned here. I have dealt with this topic in (Garrido Castellano 20 I0; Garrido Castellano 2015).

10. The construction of a collective memory recalls Susan Meiselas's interest in approaching the complexity of the societies of El Salvador and Nicaragua under situations of transformation after insurrectional moments. See Breckenridge 2006.

II. Balaguer governed Dominican Republic three times, between 1960 and 1962, 1966 and 1978, and 198696. The doce años period refers to his second period of governance, the time when most of the progress in development was made. Paradoxically enough, 
many of the most relevant Dominican cultural institutions, among them, those gathered in the Plaza de la Cultura Juan Pablo Duarte in Santo Domingo, were also established in the 1970s.

12. "Pero ciertamente esas siluetas para mí significaban mucho en aquel momento, aunque ahora vinieron a representar el anonimato. El anonimato de la ciudad. Por eso te hablaba ahora de la ciudad formal y la ciudad informal; en toda ciudad actual aparecen aquellos grupos que no cuentan; que están, pero que no aparecen en ninguna parte. Los ausentes. Los que no tienen un número, un ID, un código, o simplemente los que permanecen en las sombras de la ciudad, y solamente son requeridos y utilizados cuando se necesita la fuerza laboral; eso pasa en todas partes del mundo. Muchos países tienen la misma situación." My translation. (Garrido Castellano 20 I I).

13. The remains of the shipwreck can be approached, thus, as recognition and critical reading of the contradictions of the "idyllic landscape" for interracial, intercultural love that frequently conceal sex tourism, a phenomenon that have created a parallel economy in which low-income women can find a quick way of social promotion, not exempt, however, from a high risk of marginalization and impoverishment that the weight of remittances cannot attenuate.

14. Prostitution and migration can also be found in the origin of "remittance settlements" occupied by men whose women are working in Europe as sex workers. For a review on the relations between remittance and architecture see Lynn Lopez (20 I0). Remittances, however, widely exceeds this phenomenon and must not be solely connected with prostitution; rather, it implies a broad range of situations, gestures and stories (Burman 2002).

Carlos Garrido Castellano holds a FCT post-doctoral fellowship at the Centro de Estudos Comparatistas and the Instituto de História de Arte at the University of Lisbon. His research interests focus on visual culture, critical theory and collaborative artistic practices. He authored two books on contemporary Caribbean art. Currently he coordinates the research project "Comparing Wes. Collectivism, Emancipation, Postcoloniality".

\section{References}

Breckenridge, J. 2006. "Narrative Imag(in)ing: Susan Meiselas Documents the Sandinista Revolution in
Nicaragua." Chap. 3. In Photography and Writing in Latin America: Double Exposure, edited by Marcy E. Schwartz and Mary Beth Tierney-Tello, 59-87. Albuquerque, NM: University of New Mexico Press.

Brennan, D. 2004. What's Love Got to Do with It? Durham: Duke University Press.

Burman, J. 2002. "Remittance; Or, Diasporic Economies of Yearning." Small Axe 6 (2): 49-7I.

de América, Casa, ed. 2002. Arte contemporáneo dominicano [Contemporary Dominican Art]. Madrid: Casa de América.

Cozier, C., and T. Flores. 2012. Wrestling with the Image. Caribbean Interventions. Washington D.C:World Bank.

De Certeau, M. 1980. L'invention du quotidien. Arts de faire. Paris: Union Générale d’Editions.

De los Santos, D. 2003. Memoria de la pintura dominicana [Memory of Dominican Painting]. Santiago de los Caballeros: Grupo León Jimenes.

Duany, J. 20 I I. Blurred Borders. Chapel Hill:The University of North Carolina Press.

Enwezor, O. 2006. The Unhomely: Phantom Scenes in Global Society: 2nd International Biennial of Contemporary Art of Seville. Seville: Fundación Bienal Internacional de Arte Contemporáneo de Sevilla.

Flores, J. 20 10. The Diaspora Strikes Back. Caribeño Tales of Learning and Turning. New York: Routledge.

Fumagalli, M. C. 201 3. “'Isla Abierta' or 'Isla Cerrada'?: Karmadavis's Pre- and Post-Earthquake Hispaniola." Bulletin of Latin American Research 32 (4): 421-437.

Fumagalli, M. C. 20I5. On the Edge:Writing the Border between Haiti and Dominican Republic. Liverpool: Liverpool University Press.

Fusco, C. 1996. "Hustling for Dollars." MS Magazine, September-October: 62-70.

Garrido Castellano, C. 2010. "Rompiendo el mapa. Cuatro visiones sobre la frontera en el arte actual dominicano" Intercambio. Revista sobre Centroamérica y el Caribe, 7/8: 37-53.

Garrido Castellano, C. 20I I. Arte en diálogo. Conversaciones sobre práctica artística contemporánea, identidad e integración cultural en República Dominicana. Santo Domingo: Centro Cultural de España.

Garrido Castellano, C. 2015." On Wanting Images and Shared Responsibilities. Belkis Ramírez's "De la misma 
madera'"' Miradas. Elektronische Zeitschrift für Iberische und Ibero-amerikanische Kunstgeschichte 2:23-31.

Ginebra, F., ed. 2009. Arte dominicano joven: márgenes, género, interacciones y nuevos territorios [Recent Dominican Art: Margins, Gender, Interactions and New Territories]. Santo Domingo: Casa de Teatro.

Guillén, E. 2004. Naufragios: imágenes románticas de la desesperación [Shipwrecks: Romantic Images of Despair]. Madrid: Siruela.

Hannerz, U. 1996. Transnational Connections: Culture, People, Places. London and New York: Routledge.

Hermann, S. 2012. "Unconscious Curating." Chap. 6. In Curating in the Caribbean, edited by David Bailey, Alissandra Cummins, Alex Lapp and Allison Thompson, 85-97. Berlin:The Green Box.

Howard, D. 200 I. Coloring the Nation: Race and Ethnicity in the Dominican Republic. Oxford: Lynne Rienner Publishers.

Itzigsohn, J. 200 I. "Living Transnational Lives", Diaspora: A Journal of Transnational Studies 10 (2): 28I-296.

Kempadoo, K. 2004. Sexing the Caribbean. London and New York: Routledge.

Kempadoo, R. 201 3. "Gazing Outward and Looking Back: Configuring Caribbean Visual Culture." Small Axe 17 : |36-153.

Lynn Lopez, S. 20 I0. "The Remitance House: Architecture of Migration in Rural Mexico." Buildings \& Landscapes: Journal of the Vernacular Architecture Forum 17 (2): 33-52.

Martínez-Vergné,T. 2005. Nation \& Citizen in the Dominican Republic, 1880-1916. Durham: University of North Carolina Press.

Martínez San Miguel, Y. 200 I. "A Caribbean Confederation? Cultural Representations of Cuban and Dominican Migrations to Puerto Rico." Journal of Caribbean Literatures 3 ( I): 93-1 10.

Martínez San Miguel,Y. 2003. Caribe Two Ways. Cultura de la migración en el Caribe insular hispánico [Caribe
Two Ways. Culture of Migration in the Hispanic Insular Caribbean]. San Juan, Puerto Rico: Ediciones Callejón.

Martínez San Miguel,Y. 1998. “De ilegales e indocumentados: representaciones culturales de la migración dominicana en Puerto Rico." [On Illegal and Undocumented: Cultural Representations of Dominican Migration in Puerto Rico.]" Revista de Ciencias Sociales 4: 147-173.

Miller, J. 2012. 1844-2000. Arte dominicano. Escultura, instalaciones, medios no tradicionales y arte vitral [ 1 844-2000. Dominican Art. Sculpture, Installations, Non-Conventional Media and Stained Glass Art]. Santo Domingo: Codetel.

Mohammed, P. 20 I I. Imaging the Caribbean: Culture and Visual Translation. New York: Palgrave Macmillan.

Puri, S. 2004. The Caribbean Postcolonial. New York: Palgrave Macmillan.

Sargás, E. 2002. Race and Politics in the Dominican Republic. Miami, FL: University Press of Florida.

Sheller, M. 2003. Consuming the Caribbean. From Arawaks to Zombies. London and New York: Routledge.

Sheller, M. 2004. "Demobilizing and Remobilizing Caribbean Paradise." In Tourism Mobilities: Places to Play, Places in Play, edited by M. Sheller and J. Irry, I3-22. London and New York: Routledge.

Stephens, M. 2013. "What Is an Island? Caribbean Studies and the Contemporary Visual Artist." Small Axe 17:8-26.

Stoler, A. L., ed. 2013. Imperial Debris. On Ruins and Ruination. Durham: Duke University Press.

Torres Saillant, S. 1999. El retorno de las yolas: ensayos sobre diáspora, democracia y dominicanidad [The Return of the Yolas: Essays on Diaspora, Democracy and Dominicanness]. Santo Domingo: Manatí.

Wainwright, Leon. 20 I I. Timed Out. Art and the Transnational Caribbean. Manchester, $\mathrm{NH}$ : Manchester University Press. 